\title{
Endothelin-like immunoreactivity in human endometrium
}

\author{
I. T. Cameron ${ }^{1}$, A. P. Davenport ${ }^{2}$, C. van Papendorp ${ }^{1}$, P. J. Barker ${ }^{3}$, \\ N. S. Huskisson ${ }^{3}$, R. S. Gilmour ${ }^{3}$, M. J. Brown ${ }^{2}$ and S. K. Smith ${ }^{1}$ \\ ${ }^{1}$ Department of Obstetrics and Gynaecology, and ${ }^{2}$ Clinical Pharmacology Unit, University of \\ Cambridge Clinical School, Cambridge, UK; and ${ }^{3}$ AFRC Institute of Animal Physiology and \\ Genetics Research, Babraham, Cambridge, UK
}

\begin{abstract}
Summary. Endothelin-like immunoreactivity (ET-IR) was detected immunocytochemically in glandular epithelium and vascular endothelium of human endometrium and myometrium. Primary antibody was raised in rabbits against the carboxy-terminal heptapeptide of endothelin 1 (ET-1), ET-1 (15-21), and compared with antibodies raised against the cyclized amino-terminal, ET- $1_{(2-13)}$, and commercially obtained antibodies against the whole ET-1 or ET-3 molecule. Binding was visualized using the peroxidase technique in sections counter-stained with haemalum. Staining was seen in each of 15 sections from eight women in the proliferative (five) or secretory (three) phase of the cycle. Intense staining was present in the cytoplasm of endometrial glands and vascular endothelium, and was greatest at the endometrial-myometrial junction. The pattern of staining was similar with all primary antibodies tested. The demonstration of ET-IR in endometrium suggests that the endothelins may play a role in control of the uterine vascular bed.
\end{abstract}

Keywords: endothelin; endothelin-like immunoreactivity; endometrium; immunocytochemistry; human

\section{Introduction}

The production of a powerful vasoconstrictor in basal endometrium plays a crucial part in the mechanism of menstruation. Intense vasoconstriction of the endometrial spiral arterioles occurs immediately before the onset of menses (Markee, 1940). Furthermore, most of the functioning endometrium is shed within the first $20-24 \mathrm{~h}$ of menstruation, and subsequent haemostasis is achieved not by the deposition of platelet-fibrin plugs (Wester et al., 1978), but by vasoconstriction of the remaining basal arteriolar fragments (Christiaens et al., 1980). The best candidate for the endometrial vasoconstrictor has been prostaglandin $\mathrm{F}_{2 \mathrm{a}}$, but it is a weak pressor agent, and in vitro studies failed to demonstrate significant vasoconstrictor activity on small uterine arterioles (Maigaard et al., 1985).

The endothelins are potent vasoactive agents (Yanagisawa et al., 1988). Genomic sequencing has predicted three distinct isopeptides, ET-1, ET-2 and ET-3 (Inoue et al., 1989). In addition to its powerful vasoconstrictor actions, ET-1 stimulates the release of prostanoids and endotheliumderived relaxing factor (DeNucci et al., 1988), and is co-mitogenic for vascular smooth muscle cells. The release of immunoreactive ET-1 has recently been described from rabbit endometrial cells in primary culture (Orlando et al., 1990). We have demonstrated the presence of specific binding sites for iodinated ET-1, ET-2 and ET-3 in human uterus (Davenport et al., 1991); this study reports the localization of ET-like immunoreactivity in endometrium and myometrium using immunocytochemistry. 


\section{Materials and Methods}

\section{Materials}

ET peptides were supplied by the Peptide Institute (Osaka, Japan). Other peptides were from Cambridge Research Biochemicals, Cheshire, UK (neuropeptide Y), Peninsula, St Helens, Merseyside, UK (vasoactive intestinal peptide (VIP), eledoisin, YGGFMR, met-enkephalin, bradykinin), Bachem, Saffron Walden, Essex, UK (calcitonin gene-related peptide CGRP), atrial natriuretic factor (ANF), cholecystokinin (CCK), pentagastrin, somatostatin, substance $\mathrm{P}$, dynorphin A(1-6)), and Sigma Chemicals, UK (epidermal growth factor (EGF)). Commercial rabbit polyclonal antisera RAS 6901-N and RAS 6911-N were obtained from Peninsula.

\section{Antisera}

Primary antibodies were raised in rabbits to the carboxy-terminal heptapeptide of ET-1, ET-1 $1_{(15-21)}$, synthesized using solid phase tertiary butoxycarbonyl (t-BOC) chemistry. The identity of the peptide was confirmed by amino acid sequencing before conjugation to purified protein derivative of tuberculin using sulfosuccinimidyl 4-( $N$-maleimidomethyl) cyclohexane-1-carboxylate. For comparison, antibodies that had been raised in rabbits to the cyclized aminoterminal, ET- $1_{(2-13)}$ were used. Commercial rabbit polyclonal antibodies against whole ET-1 (Peninsula RAS 6901-N, which crossreacts with ET-1 $(100 \%)$, human ET-1 $(17 \%)$, ET-2 $(<10 \%)$ and ET-3 $(<10 \%))$ or ET-3 (Peninsula RAS $6911-\mathrm{N}$, which crossreacts with ET-3 $(100 \%)$, ET-2 $(<1 \%)$ and ET-1 $(<2 \%))$ were also evaluated. Solid phase immunoabsorbent assay (ELISA), and radioimmunoassay, confirmed that antibodies recognized unlabelled and iodinated ET peptides respectively.

\section{Evaluation of antisera}

Positive controls included the detection of staining in the cytoplasm of human umbilical artery and vein endothelial cells. No staining was seen when primary antibody was omitted or pre-immune sera substituted. Controls were also performed by pre-absorbing antibodies with synthetic ET peptides $\left(10^{-6} \mathrm{~mol}^{-1}\right)$ for $48 \mathrm{~h}$ to abolish staining. Specificity of the antisera was determined by incubating primary antibodies with peptides unrelated to the endothelins, which may be present in uterine tissues, or which have a similar cyclic structure, used at $10^{-6}$ mol $1^{-1}$; CGRP, ANF, VIP (human), CCK-4, pentagastrin, somatostatin, substance P, eledoisin, dynorphin A(1-6), YGGFMR, $\left(\mathrm{Met}^{5}\right)$-enkephalin, bradykinin, neuropeptide $\mathrm{Y}$ and EGF.

No staining was detected in negative control sections in which primary antibody had been omitted, or pre-immune rabbit sera substituted at the same concentration as primary antibody.

\section{Immunocytochemistry}

Tissue was collected from eight women undergoing hysterectomy for benign disease. Informed consent was obtained, and the study was approved by the Cambridge Health Authority District Ethical Committee. Samples were immediately snap-frozen in liquid nitrogen, and stored at $-80^{\circ} \mathrm{C}$ until processed.

Thick cryostat sections, $30 \mu \mathrm{m}$, (15 from each patient), taken through the whole thickness of endometrium and adjacent myometrium, were thaw-mounted onto gelatin-subbed slides and allowed to warm to room temperature. The sections were fixed in $4 \%$ formaldehyde, and incubated with $10 \%$ goat serum to block nonspecific staining. Sections were then incubated with primary antibody for $60 \mathrm{~h}$ at a dilution of $1: 300(\mathrm{v} / \mathrm{v})$, and tested over the range $\mathrm{l}: 100$ to $1: 1000$. Binding was visualized using an anti-rabbit second antibody (diluted 1:200, (v/v) in 0.05 mol phosphate-buffered saline $\left.\mathrm{I}^{-1}, \mathrm{pH} 7 \cdot 4\right)$ followed by rabbit peroxidase-anti-peroxidase $(1: 400, \mathrm{v} / \mathrm{v})$. The complex was detected with diaminobenzidine and hydrogen peroxide in $0.05 \mathrm{~mol}$ Tris $\mathrm{HCl}^{-1}(\mathrm{pH} \mathrm{7.4})$ in sections counterstained with haemalum (Sternberger et al., 1970).

\section{Results}

Five specimens were in the proliferative phase (days $2,6,7,13,14$ ) and three in the secretory phase (days 15, 20,23), based on the date of the last menstrual period, and confirmed by histological assessment.

Endothelin-like immunoreactivity was detected in all tissues examined, and with each antibody, over the concentration range $1: 100$ to $1: 1000$. Although the pattern of staining with the carboxyterminus antibody, ET-1 $(15-21)$ was similar to all other antibodies tested, the intensity of staining was lower with both ET-1 $(2-13)$, and the commercial antibody RAS 6901-N, tested at the same 
dilution, and processed in the same assay (Figs 1 and 2). A reduced intensity of staining was also seen with the antibody raised against ET-3 (RAS 6911-N). Staining was localized to the cytoplasm of endometrial glandular epithelium, and was most intense, both in terms of the density of the reaction product, and the number of glandular cells stained, at the endometrial-myometrial junction (Fig. 1a,d). All gland cells were stained in secretory tissue (Fig. 1e), but there was a more heterogeneous picture in proliferative tissue. Stromal staining was only detected between basal glandular tissue in the specimen from day 7.
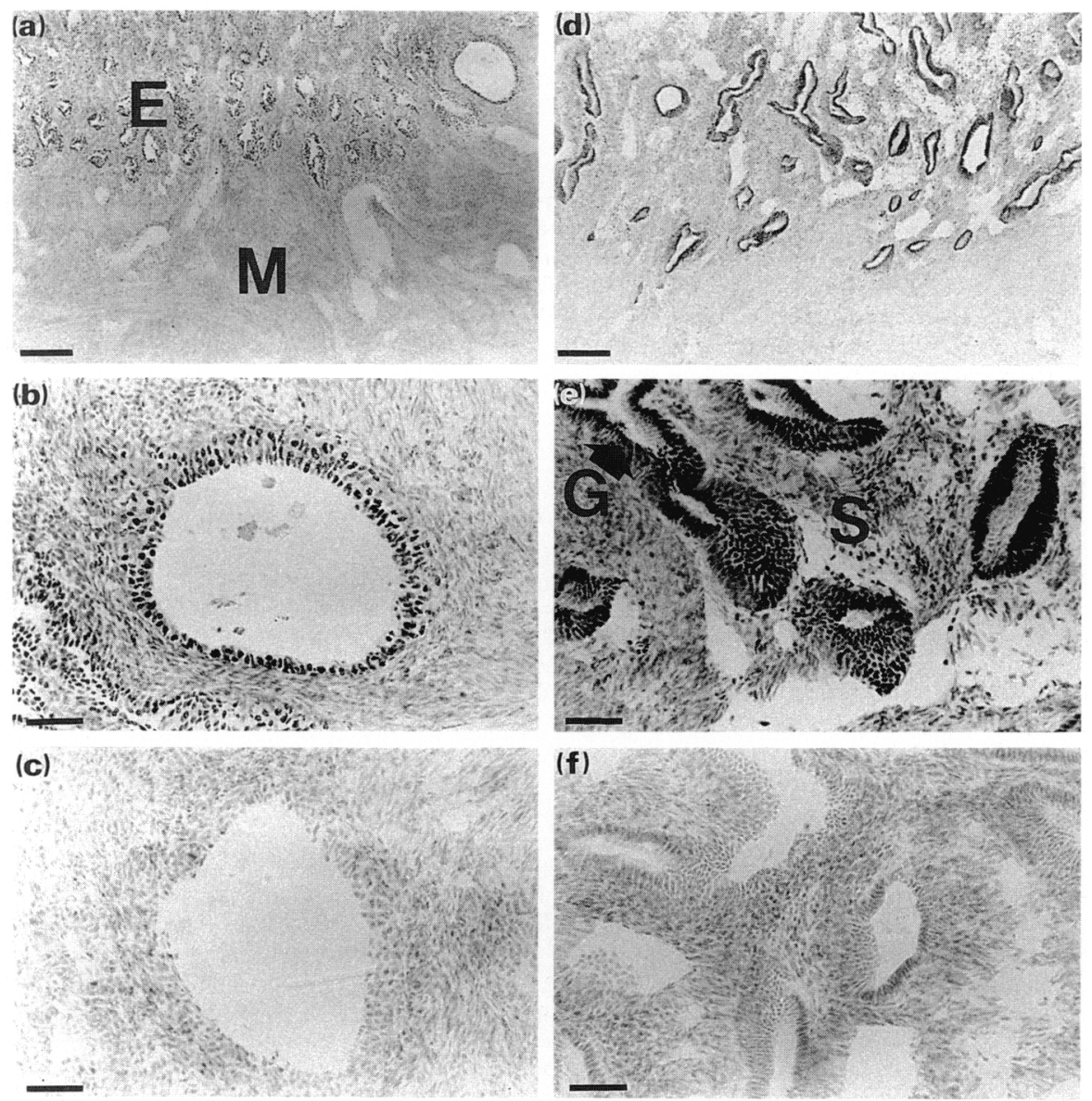

Fig. 1. Examples of endothelin-like immunoreactivity in human (a,b) proliferative endometrium, (d, e) secretory endometrium and (c, f) controls. Cryostat sections, $30 \mu \mathrm{m}$, were fixed and incubated with primary antibody $\left(\mathrm{ET}-\mathrm{l}_{(15-21)}\right)$ for $60 \mathrm{~h}$ at $4^{\circ} \mathrm{C}$, at a concentration of $1: 300$ $(v / v)$. Binding of antibody was visualized using the unlabelled antibody enzyme method in sections counter-stained with haemalum. Intense binding was seen in glandular epithelium and vascular endothelium at the endometrial-myometrial junction. E: endometrium; $\mathbf{M}$ : myometrium; G: gland; S: stroma. Scale bars: $200 \mu \mathrm{m}$ (a, d) and $25 \mu \mathrm{m}(\mathrm{b}, \mathrm{c}, \mathrm{e}, \mathrm{f})$.

Endothelin-like immunoreactivity was also detected in the cytoplasm of vascular endothelial cells in endometrium and myometrium (Fig. 2a). No staining was seen in vascular smooth muscle cells or myometrium. Staining was not affected by pre-absorption with non-ET peptides, but was abolished after pre-absorption of the ET-1 $1_{(15-21)}$ antibody with ET-1, ET-2 and ET-3. Staining was not affected by pre-absorbing ET-1 $(2-13)$ antisera with ET-3. 

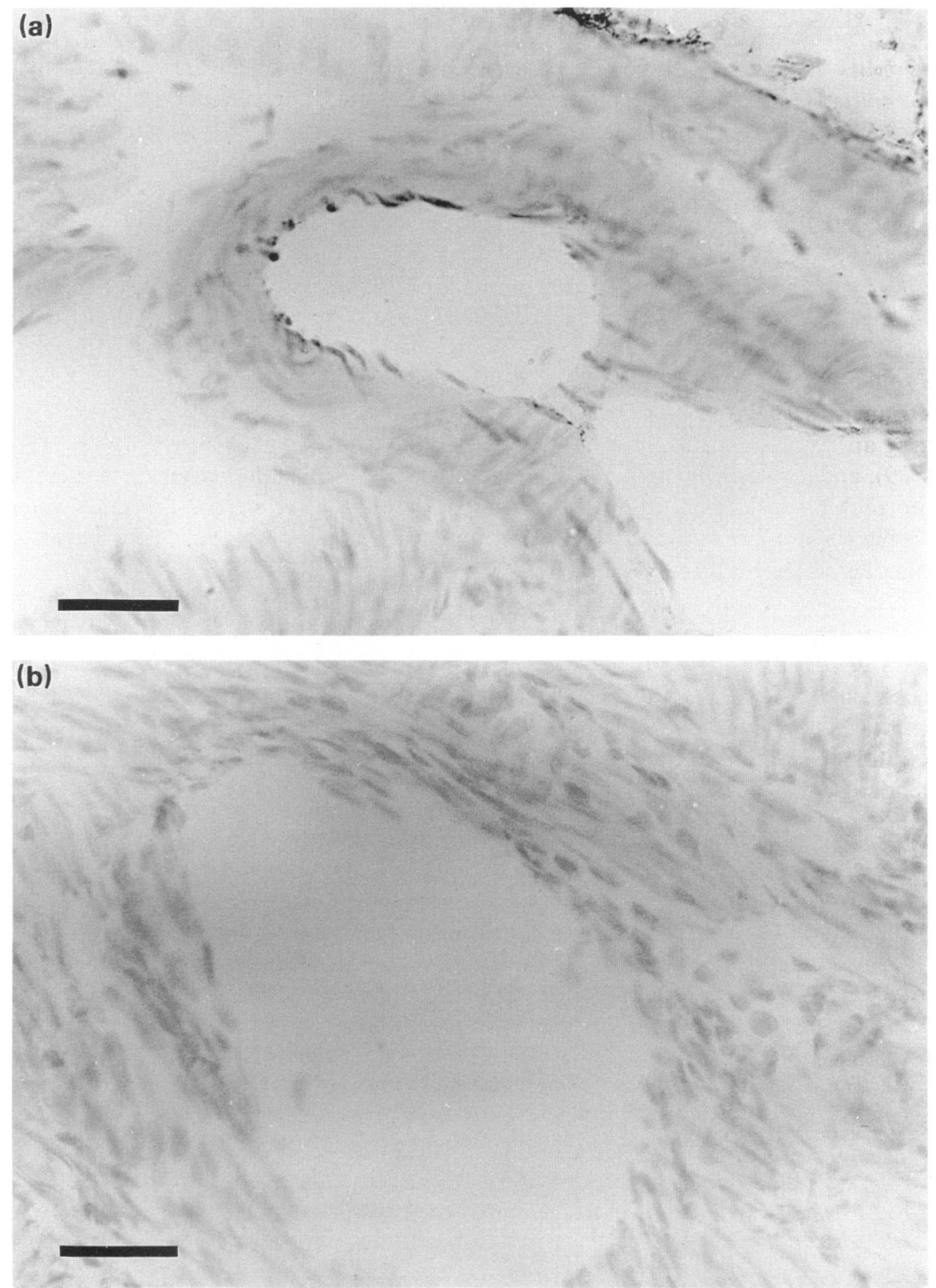

Fig. 2. Examples of endothelin-like immunoreactivity in human (a) myometrial vascular endothelium and (b) control. $30 \mu \mathrm{m}$ cryostat sections were fixed and incubated with primary antibody $\left(E T-1_{(15-21)}\right)$ for $60 \mathrm{~h}$ at $4^{\circ} \mathrm{C}$, at a concentration of $1: 300(\mathrm{v} / \mathrm{v})$. Binding of antibody was visualized using the unlabelled antibody enzyme method in sections counterstained with haemalum. Staining is seen in vascular endothelial cells but not in vascular smooth muscle or myometrium. Scale bar: $25 \mu \mathrm{m}$. 


\section{Discussion}

Endothelin-like immunoreactivity was detected in both vascular endothelium, and endometrial glandular epithelium of human uterus. The primary antibodies showed specificity for ET peptides, but no detectable crossreactivity with unrelated peptides. However, it is not possible to determine the precise nature of the ET-IR owing to crossreactivity between the various ET isoforms using antibody directed towards the common carboxy terminus. The pattern of staining seen with the ET-3 antibody may represent the presence of this peptide, or crossreactivity with some other untested endogenous peptide. The suggestion that the ETs are present in other nonendothelial tissues is supported by studies that have demonstrated the localization of ET-IR or the expression of ET mRNA in a variety of nonvascular epithelia (MacCumber et al., 1989; Baley et al., 1990; Marciniak et al., 1992).

The role of uterine ET is not yet established. Release of immunoreactive ET-1 from rabbit endometrium was stimulated by analogues of oxytocin and vasopressin (Orlando et al., 1990), supporting an involvement in the paracrine control of myometrial contractions (Bousso-Mittler et al., 1989), and subsequent work has demonstrated ET-IR on endometrial surface epithelium in immature rabbits, with localization to endometrial stroma after steroid priming (Maggi et al., 1991). In the present study, the pattern of staining in human endometrium was similar to that of autoradiographically localized binding sites for iodinated ET-1, ET-2 and ET-3, concentrated around basal endometrial glands (Davenport et al., 1991). Intense vasoconstriction in the basal endometrium appears to play a crucial role in the mechanism of menstruation (Markee, 1940; Christiaens et al., 1980). The demonstration of both ET-IR and specific binding of iodinated peptide concentrated at the endometrial-myometrial junction might offer an alternative to $\mathrm{PGF}_{2 a}$ as the endometrial vasoconstrictor. The immunocytochemical localization of ET-IR in basal endometrium suggests that these potent peptides may not only be candidates for the endometrial vasoconstrictor, but may also be involved in the mediation of uterine contractions, endometrial proliferation and implantation.

C. van Papendorp is supported by Grant Number 31 to I. T. Cameron from the East Anglian Regional Health Authority. The work was also supported by grants from the British Heart Foundation, the Nuffield Foundation, and the Wellcome Trust, to A. P. Davenport.

\section{References}

Baley, P.A., Resink, T.J., Eppenberger, U. \& Hahn, A.W.A. (1990) Endothelin messenger RNA and receptors are differentially expressed in cultured human breast epithelial and stromal cells. Journal of Clinical Investigation 85, 1320-1323.

Bousso-Mittler, D., Kloog, Y., Wollberg, Z., Bdolah, A., Kochva, E. \& Sokolovsky, M. (1989) Functional endothelin/sarafotoxin receptors in the rat uterus. Biochemical and Biophysical Research Communications 162, 952-957.

Christiaens, G.C.M.L., Sixma J.J. \& Haspels, A.A. (1980) Morphology of haemostasis in menstrual endometrium. British Journal of Obstetrics and Gynaecology 87, 425-439.

Davenport, A.P., Cameron, I.T., Smith, S.K. \& Brown, M.J. (1991) Binding sites for iodinated endothelin-1, endothelin-2 and endothelin-3 demonstrated on human uterine glandular epithelial cells by quantitative high resolution autoradiography. Journal of Endocrinology 129, 149-154.

DeNucci, G., Thomas, R., D'Orleans-Juste, P., Antunes, E., Walder, C., Warner, T.D. \& Vane, J.R. (1988)
Pressor effects of circulating endothelin are limited by its removal in the pulmonary circulation and by the release of prostacyclin and endothelium-derived relaxing factor. Proceedings of the National Academy of Sciences, USA 85, 9797-9800.

Inoue, A., Yanagisawa, M., Kimura, S., Kasuya, Y., Miyauchi, T., Goto, K. \& Masaki, T. (1989) The human endothelin family: three structurally and pharmacologically distinct isopeptides predicted by three separate genes. Proceedings of the National Academy of Sciences, USA 86, 2863-2867.

MacCumber, M.W., Ross, C.A., Glaser, B.M. \& Snyder, S.H. (1989) Endothelin: visualization of mRNAs by in situ hybridization provides evidence for local action. Proceedings of the National Academy of Sciences, USA 86, 7285-7289.

Maggi, M., Vannelli, G.B., Peri, A., Brandi, M.L., Fantoni, G., Giannini, S., Torrisi, C., Guardabasso, V., Barni, T., Toscano, V., Massi, G. \& Serio, M. (1991) Immunolocalization, binding, and biological activity of endothelin in rabbit uterus: effect of ovarian steroids. American Journal of Physiology 260, E292-E305. 
Maigaard, S., Forman, A. \& Andersson, K-E. (1985) Different responses to prostaglandin $F_{2 a}$ and $E_{2}$ in human extra- and intramyometrial arteries. Prostaglandins 30, 599-607.

Marciniak, S.J., Plumpton, C., Barker, P.J., Huskisson, N.S. \& Davenport, A.P. Localization of immunoreactive endothelin and proendothelin in human lung. Pulmonary Pharmacology (in press).

Markee, J.E. (1940) Menstruation in intraocular endometrial transplants in the rhesus monkey. Contributions to Embryology 28, 219-308.

Orlando, C., Brandi, M.L., Peri, A., Giannini, S., Fantoni, G., Calabresi, E., Serio, M. \& Maggi, M. (1990) Neurohypophyseal hormone regulation of endothelin secretion from rabbit endometrial cells in primary culture. Endocrinology 126, 1780-1782.
Sternberger, L.A., Hardy, P.H., Jr, Cuculis, J.J. \& Meyer, H.G. (1970) The unlabeled antibody-enzyme method of immunocytochemistry. Preparation and properties of soluble antigen antibody complex (horseradish peroxidase-antihorseradish peroxidase) and its use in identification of spirochetes. Journal of Histochemistry and Cytochemistry 18, 315-333.

Wester, J., Sixma, J.J., Gueze, J.J. \& Van der Veen, J. (1978) Morphology of the early hemostasis in human skin wounds. Laboratory Investigation 39, 298-311.

Yanagisawa, M., Kurihara, H., Kimura, S., Tomobe, Y., Kobayashi, M., Mitsui, Y., Yazaki, Y., Goto, K. \& Masaki, T. (1988) A novel potent vasoconstrictor peptide produced by vascular endothelial cells. Nature 332, 411-415.

Received 23 May 1991 